\title{
A Growth Cabinet for the Study on Biotronics
}

\section{Design and Performance}

\author{
Tsuyoshi Matsui,* Hiromi EguchI,* Yoshiaki HaNAmI,** \\ Shigeru HANDA** and Teijiro TERAJIMA** \\ *Biotron Institute, Kyushu University. \\ ** Koito Industries, Ltd.
}

(Received May 22, 1971)

\author{
高性能グロースキャビネットの試作 \\ I ．設計製作とその性能 \\ 松井 健*・江口弘美*・花見至晃**。 \\ 半田 繁**.寺島禎二郎** \\ * 九州大学生物環境調節研究センター, ** 小系工業株式会社
}

生物環境調節の基礎的な研究をおこなうには, 環境要素の精密な制御と生物反応の詳細な解析が 必要と考えられる. 本研究は, 環境制御方法の発達に資するために, より高度の制御能力をもつグ ロースキャビネットの設計と試作をおこない，その性能を解析して次の結果を得た。

1) 温度制御は $-5^{\circ} \mathrm{C}$ から $+40^{\circ} \mathrm{C}$ の範囲で可能であり, 精度は $\pm 0.5^{\circ} \mathrm{C}$ 以内であった. プロ グラムコントロールの場合, 温度勾配, $10^{\circ} \mathrm{C} / 30 \mathrm{~min}$ に十分追従できた. また P.I. D. 動作によっ て off-set は十分に除去された.

2) 相対湿度は 40 80\% の範囲（温度 $10 \sim 40^{\circ} \mathrm{C}$ ) で制御され，制御精度は $\pm 3 \%$ 以内であった。 プログラムコントロールの場合, 湿度勾配，10\%/15 min に追従することができた.

3） 16 個の小型フォンを用いることにより，風速，風速分布，風向をほぼ均一に保つことができ， 定常状態での風速分布は, $0.2 \sim 0.5 \mathrm{~m} / \mathrm{sec}$ の範囲にあった.

4) 人工照明は 45 個の $40 \mathrm{~W}$ 螢光灯 (真天然純正色) と 8 個の $100 \mathrm{~W}$ タングステンランプに よったが，床面上 $50 \mathrm{~cm}$ の位置で, $20,000 \operatorname{lux}\left(110 \mu \mathrm{W} / \mathrm{mm}^{2}\right)$ の光強度を得ることができた. しか し, この光のスペクトル分布が, 植物実験に適しているか否かは, 今後の実験の課題として残され ている.

Summary For studies on biotronics of fundamental problems in environmental control in biology, high accurate control of environmental factors was demanded. The growth cabinet is considered as an effective tool for such purpose. Present report deals with a trial to develop a growth cabinet with capacity of high accurate control, and following results were obtained.

1) It became possible to control temperature from $-5^{\circ} \mathrm{C}$ to $40^{\circ} \mathrm{C}$ with accuracy of \pm $0.5^{\circ} \mathrm{C}$. The P.I. D. control action contributed to remove off-set and cyclic variation in temperature control. In the case of program control, temperature gradient of $10^{\circ} \mathrm{C} / 30$ min was obtained.

2) Relative humidity was controlled from $40 \%$ to $80 \% \pm 3 \%$ at temperature range from $10^{\circ} \mathrm{C}$ to $40^{\circ} \mathrm{C}$. In program control, falling and rising gradient of relative humidity was $10 \% / 15 \mathrm{~min}$.

3) Wind direction, velocity and distribution were kept uniform by 16 fans installed at the side of air supply compartment. Wind velocity ranged from $0.2 \mathrm{~m} / \mathrm{sec}$ to $0.5 \mathrm{~m} / \mathrm{sec}$.

4) The canopy provided 45 fluorescent lamps of $40 \mathrm{~W}$ (FLR40S $-\mathrm{W}-\mathrm{SDL}-\mathrm{AP} / \mathrm{M})$ and 8 incandescent lamps of $100 \mathrm{~W}$. At $50 \mathrm{~cm}$ above floor 20,000 lux $\left(110 \mu \mathrm{W} / \mathrm{mm}^{2}\right)$ of light intensity was obtained. However, it is not clear whether the spectrum distribution of the light is suitable for plant, or not. 


\section{INTRODUCTION}

Since phytotron was used for the studies on relations between environmental factors and plant responses, ${ }^{(4)}$ many workers have offered numbers of interesting criteria in biology and have greatly contributed towards researches in agriculture, plant physiology and other concerned fields. ${ }^{(2)}$ There are, however, many problems in phytotron; for example, it is not known how high accuracy is necessary for environmental control, and also how many kinds of environmental factors should be controlled. For these problems, it is necessary to develop biotronics which deals with fundamental methodology for environmental control in biology. The growth cabinet for high accurate control of environmental factors is considered as an effective tool for the study on biotronics.

This report presents a trial to make a growth cabinet which can control temperature and relative humidity, independenty, with high accuracy.

\section{ITEMS OF SPECIFICATION}

Type: Reach-in type Growth Cabinet.

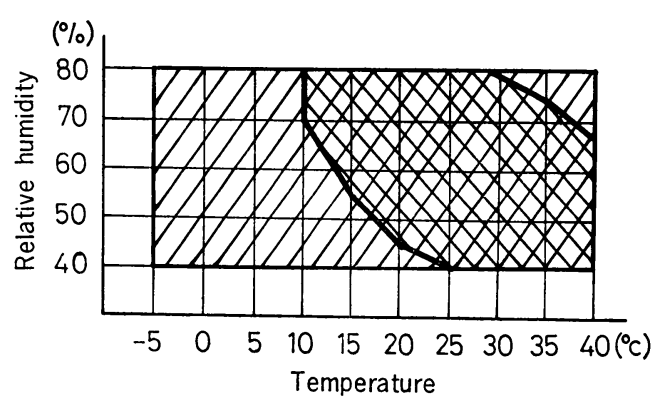

VIID Temperature control range.

Temperature and relative humidity control range.

Fig. 1 Control range of temperature and relative humidity.
Inside dimention of growth compartment: $150 \mathrm{~cm}(\mathrm{~W}) \times 100 \mathrm{~cm}(\mathrm{D}) \times 100 \mathrm{~cm}(\mathrm{H})$.

Control terms for temperature: 1) Control range; $\left.-5^{\circ} \mathrm{C} \sim+40^{\circ} \mathrm{C}, 2\right)$ Amplitude of cyclic variation; $0.5^{\circ} \mathrm{C} \sim 5^{\circ} \mathrm{C}$.

Control terms for relative humidity: Range shown in Fig. 1.

Velocity of air flow: $0.3 \mathrm{~m} / \mathrm{sec}$.

Artificial light: 20,000 lux.

\section{BASIC DESIGN}

The feedback control system was adopted for temperature and relative humidity control in the growth cabinet, as illustrated in Fig. 2. In order to obtain accuracy of temperature control of $\pm 0.5^{\circ} \mathrm{C}$, on-off control action should not be suitable, because temperature control by on-off control action brings forth cyclic variation of controlled temperature even under no load condition. To remove the cyclic variation, P.I.D. control action $^{(3)}$ was adopted for the temperature control. A sine wave input was interlocked to the growth cabinet for the purpose of study on the effect of cyclic variation of temperature on plant.

Figure 3 shows the schematic diagram of the temperature control system. In the return air compartment, temperature is detected with the element of platinum wire fused in glass, and the detected signal is led into the bridge box, which supplies voltage of $10 \mathrm{mV} \mathrm{D}$. C. at $50^{\circ} \mathrm{C}$ and $0 \mathrm{mV} \mathrm{D.C.} \mathrm{at}-10^{\circ} \mathrm{C}$. Temperature information which is exchanged into voltage value, is led to P. I. D. controller as feedback signal, and at the same time, recorded as temperature value by the electronic self balancing recorder. One or two sets of cooling coils are operated continuously to keep air temperature lower than the desired value. The air which passed through the

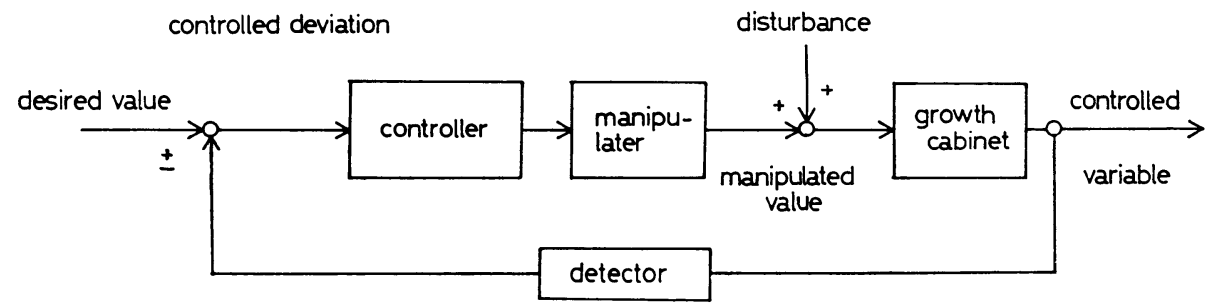

Fig. 2 Block diagram of feedback process control system. 


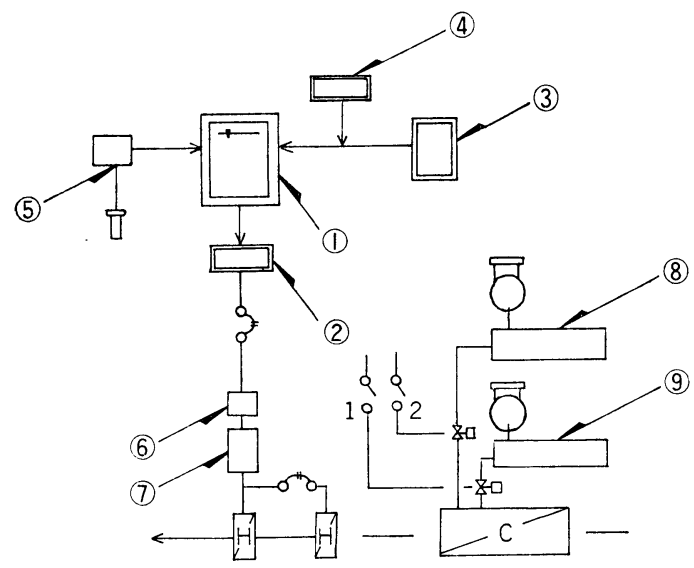

Fig. 3 Schematic diagram of temperature control. 1, Electronic recording controller. 2, P.I. D. controller. 3, Program controller. 4, Sine wave signal generator, 5 , Psychrometer transmitter. 6, Pulse signal transmitter. 7, S. C.R. electric manipulator. 8, First step refrigerator. 9, Second step refrigerator.

cooling coils is heated by the electric heater, of which capacity is regulated through the S.C.R. which received the signal from the P.I.D. controller. In the case of control of constant temperature, desired value is set by the P.I.D. controller. In the case of control of variable temperature, the program generator is used in conjunction with the $\mathrm{P}$. I.D. controlling meter, and programed value is controlled through the cascade control by the P. I. D. control action. When temperature is controlled by sine wave generator, cyclic variation of temperature is generated. The amplitude and the period of the sine waves are variable and the cyclic variation of temperature is changeable from $\pm 0.5^{\circ} \mathrm{C}$ to $\pm 5.0^{\circ} \mathrm{C}$.

The P. I. D. control action was also adopted for relative humidity control. In the return air compartment, relative humidity is detected by the psychrometer detector (HMT$11 \mathrm{sp}$. Yokogawa electric works Ltd.) and is

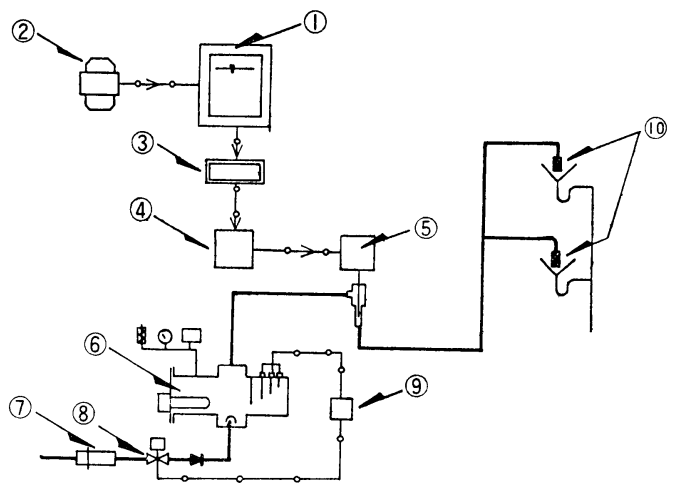

Fig. 4 Schematic diagram of humidity control. 1, Electronic recording controller. 2, Psychrometer transmitter. 3, P. I. D. controller. 4, Electric and electronic positioner. 5, Modutrol steam valve. 6, Electric steam boiler. 7 , Water filter. 8 , Solenoid valve. 9 , Water level controller. 10, Steam jet.

Table 1 Main Equipments

\begin{tabular}{|c|c|c|}
\hline Items & Number & Specifications \\
\hline 2-Pen recording controller & 1 & $\begin{array}{l}\text { Control scale range; Temp., }-10^{\circ} \mathrm{C} \sim+50^{\circ} \mathrm{C} \\
\text { Relative humidity; } 20 \sim 100 \%\end{array}$ \\
\hline Sine wave signal generator & 1 & $\begin{array}{l}\text { Output signal voltage; } 0 \sim 5 \mathrm{mV} \text { D. C. } \\
\text { Desired frequency period; } 1,2,4,6,12,24 \mathrm{~min} \\
\text { Indicating scale; }-10^{\circ} \mathrm{C} \sim+50^{\circ} \mathrm{C} \\
\text { Proportional with integral and derivative }\end{array}$ \\
\hline Temperature controller & 1 & $\begin{array}{l}\text { Input; } 0 \sim 10 \mathrm{mV} \mathrm{D.} \mathrm{C.} \mathrm{Output;} 5 \sim 25 \mathrm{~mA} \mathrm{D.C.} \\
\text { Proportional band; } 0 \sim 200 \text { reversible } \\
\text { Integral time; } 0.1 \sim 50 \mathrm{~min} \\
\text { Derivative; } 0 \sim 10 \mathrm{~min}\end{array}$ \\
\hline Program controller & 1 & Output; $0 \sim 10 \mathrm{mV}$ D. C. \\
\hline First step refrigerator & 1 & Hermetic $\mathrm{F}-22$ compressor; $0.75 \mathrm{kw}, 3$ phase, $200 \mathrm{~V}$ \\
\hline Second step refrigerator & 1 & Hermetic F-22 compressor; $1.5 \mathrm{kw}, 3$ phase, $200 \mathrm{~V}$ \\
\hline Electric steam boiler & 1 & $200 \mathrm{~V}, 3$ phase, $7.0 \mathrm{kw}$ \\
\hline Electric heater & 1 & $200 \mathrm{~V}, 3$ phase, $5+10 \mathrm{kw}$ \\
\hline
\end{tabular}


exchanged into voltage of $10 \mathrm{mV}$ at $100 \%$ and $0 \mathrm{mV}$ at $20 \%$ (error; $0.5 \%$, sensitivity; $0.15 \%$ of full scale) by the transducer. The voltage signals of relative humidity is led to the electronic self balancing recorder and also led to the P. I. D. controller as the feedback signal. Control signal is led to the modutrol motor for the regulation of steam supply. (1) The dehumidifying control is performed by following system; one or two sets of the cooling coils are continuously operated, so that the air which passed through the cooling coils is always kept below the apparatus dew point. The reheating capacity of the electric heater is regurated through the silicon controlled rectifier. Figure 4 shows the diagram of control system of relative humidity. In order to make the distribution of wind velocity uniform, the air supply compartment which has volumetric ratio of 0.9 with respect to the growth compartment, was installed at one of the flank sides of the growth compartment. The main equipments are shown in Table 1.

\section{CONSTRUCTION OF GROWTH CABINET}

Figures 5 and 6 show the general view and the sectional structure of the growth cabinet. The interior and the exterior of the cabinet were finished with stainless steel.

The growth compartment was provided at central part and flanked with the air supply compartment on one side and also with the return air compartment on the other side. Figure 7 shows the control panel which

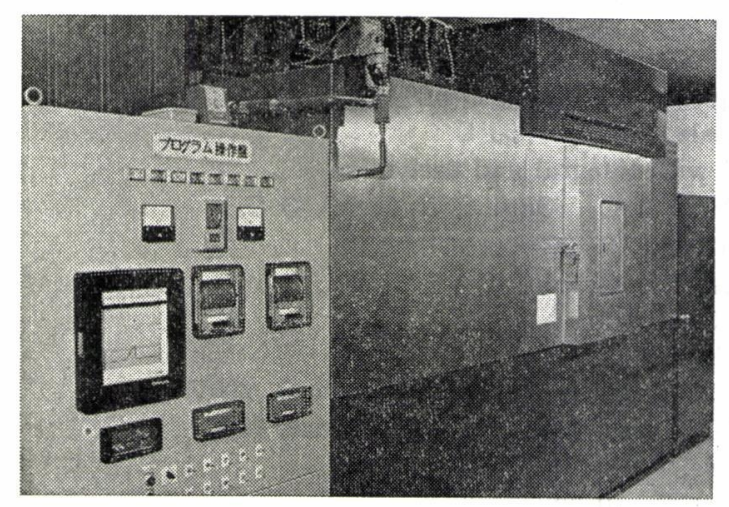

Fig. 5 General view of growth cabinet.

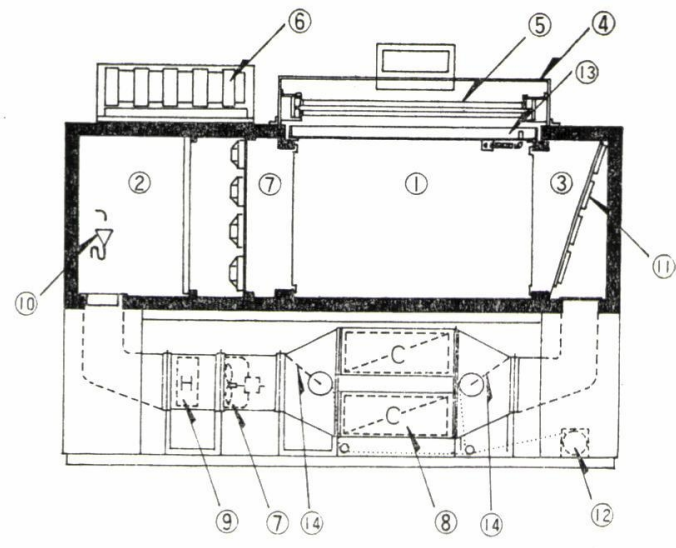

Fig. 6 Sectional structure of growth cabinet. 1, Growth compartment. 2, Air supply compartment. 3, Return air compartment. 4, Lamp unit. 5, Lamps. 6, Ballast. 7, Fans. 8, Cooling coil. 9, Electric heater. 10, Steam jet. 11, Shutter. 12, Dumper moter. 13, Water layer. 14, Dumpers.

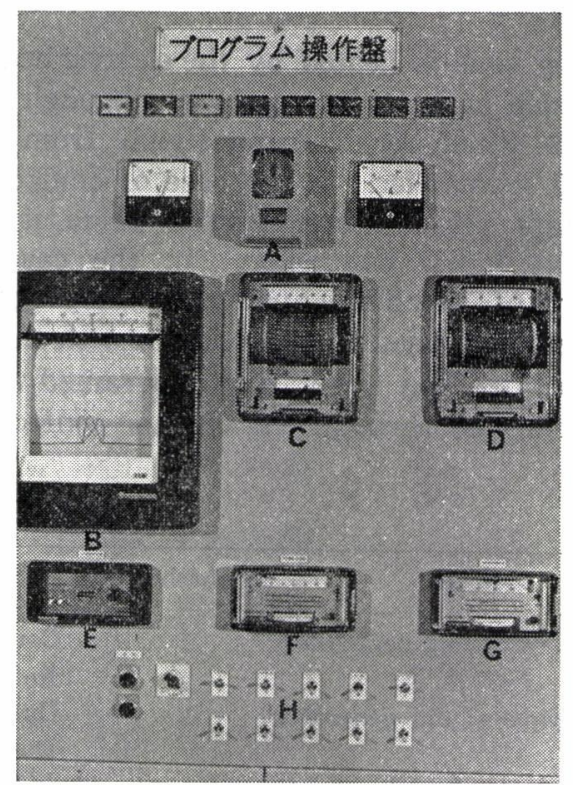

Fig. 7 Control panel.

A, Time switch of artificial light. B, Recorder of temperature and relative humidity. C, Program controller for temperature. D, Program controller for relative humidity. E, Sine wave signal generator. F, P.I.D. controller for temperature. G, P. I. D. controller for relative humidity. $\mathrm{H}$, Switches of lamps, refrigerator and humidifier.

Environ. Control in Biol. (生物環境調節) 
provides time switch of artificial light, recorder of temperature and relative humidity, program controller for temperature control, program controller for relative humidity, sine wave signal generator, P.I.D. controller for temperature, P.I.D. controller for relative humidity, and switches of lamps, refrigerators and humidifier.

Sixteen small size fans were installed behind perforated stainless steel plate at the side of the air supply compartment to keep wind direction, velocity and distribution uniform. In the return air compartment, 4 split shutters were installed for modulation of air flow. These appearances are shown in Figs. 8 and 9. Figure 10 shows psychrometer detector (HMT-11 sp) in the return air compartment.

In cooling system, two passes of air flow were provided on parallel. Each of the passes

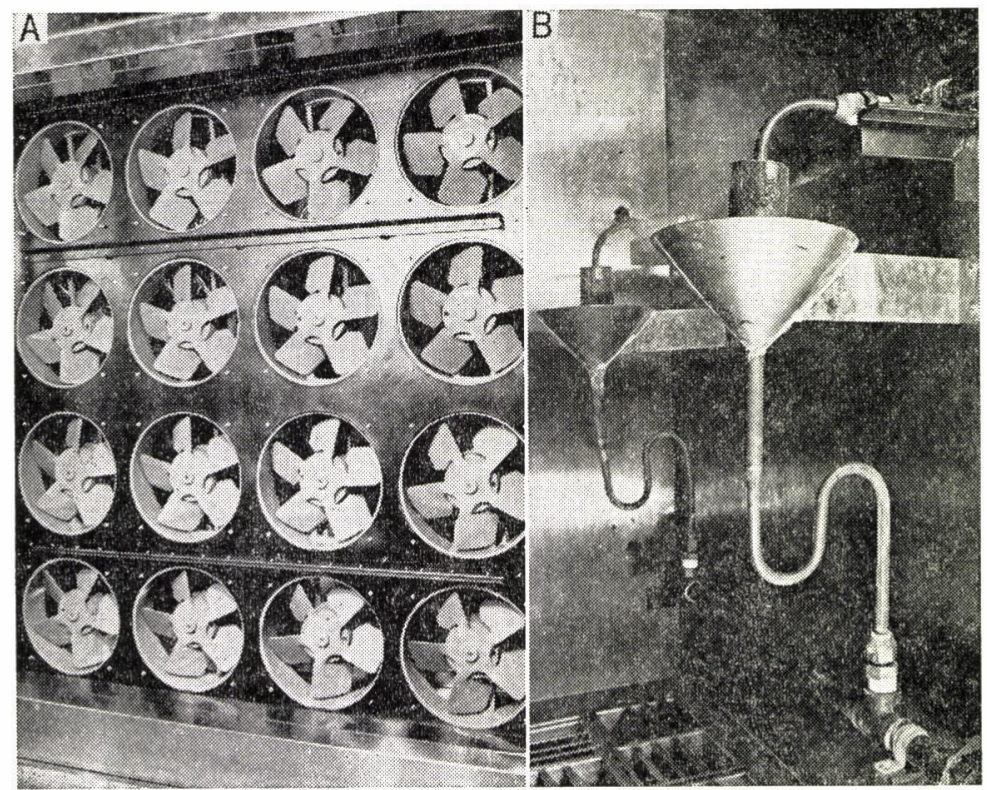

Fig. 8 Air supply compartment.

A, Fans. B, Steam je's.

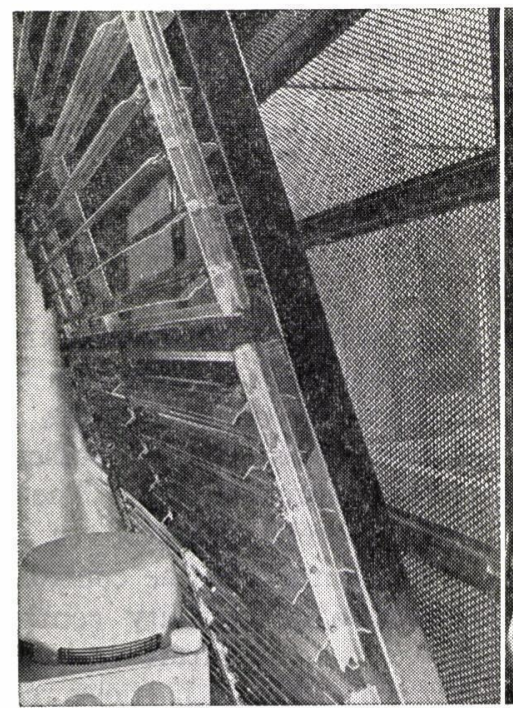

Fig. 9 Return air compartment.

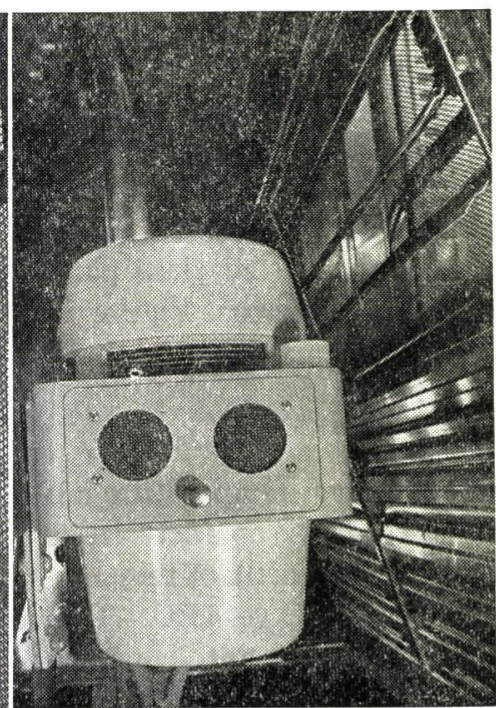

Fig. 10 Psychrometer detector. 
of air flow equipped a cooling unit which consists of two cooling coils with capacity of $2,500 \mathrm{kcal} / \mathrm{h}$ and $5,000 \mathrm{kcal} / \mathrm{h}$, respectively. The air pass can be automatically changed over by damper drived by modutrol motor. This system facilitates smooth defrosting performance, that is, when one cooling unit frosts in low temperature control, the air pass is changed over to use other cooling unit. Two cooling coils in a cooling unit make it possible to change cooling capacity on three stages of $2,500,5,000$, and $7,500 \mathrm{kcal}$ $/ \mathrm{h}$, according to change of thermal load. Humidifier was installed in the air supply compartment. Capacity of steam supply is regulated by P.I.D. control action as mentioned above.

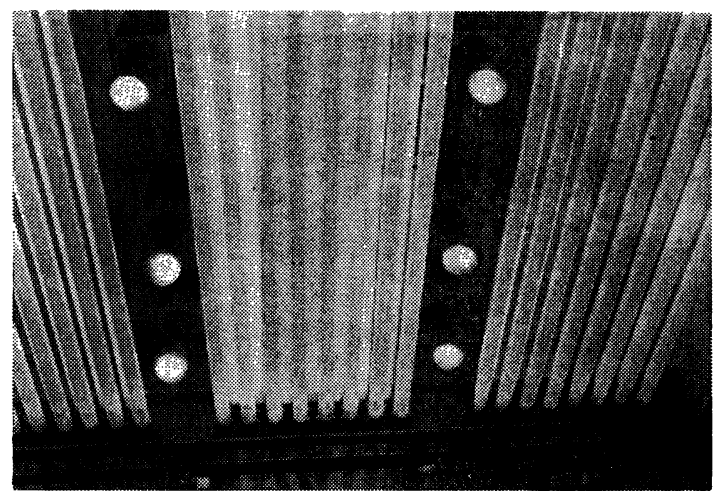

Fig. 11 Placement of lamfs.

Lamp unit provides 45 fluorescent lamps of $40 \mathrm{~W}$ (FLR $40 \mathrm{~S} \cdot \mathrm{W}-\mathrm{SDL}-\mathrm{AP} / \mathrm{M}$ ) and 8 incandescent lamps of $100 \mathrm{~W}$. The canopy with lamps was partitioned from the growth compartment by glass plate and exchangeable when it is necessary to change the kind of lamps. Water layer of $5 \mathrm{~cm}$ in thickness was circulated constantly on the glass plate to remove radiation from lamps. Figure 11 shows the placement of lamps.

\section{PERFORMANCE}

Figures 12 and 13 show temperature-fall and -rise characteristics. These characteristics demonstrated possibility to control temperature at the range from $-5^{\circ} \mathrm{C}$ to $40^{\circ} \mathrm{C}$. This performance achieved the result expected for control range of temperature. Figure 14 shows temperature controlled by the program

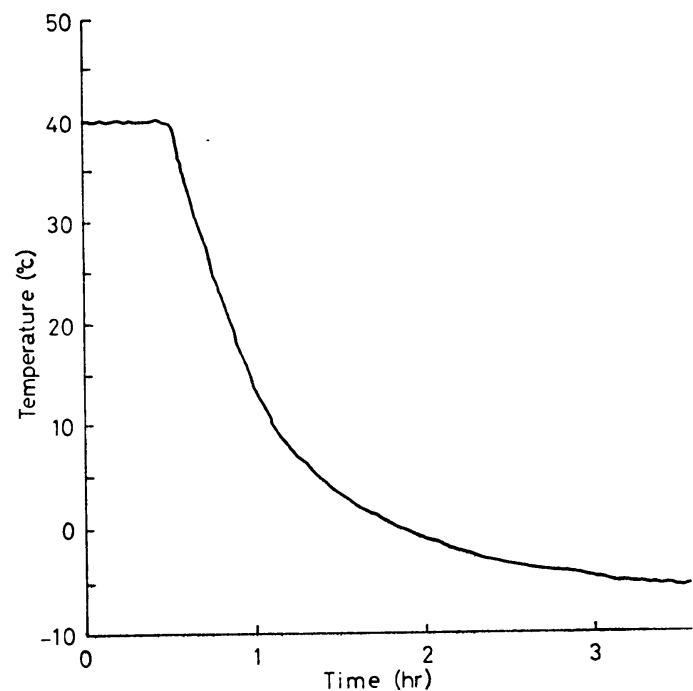

Fig. 12 Temperature-fall characteristic from $40^{\circ} \mathrm{C}$ to $-5^{\circ} \mathrm{C}$.

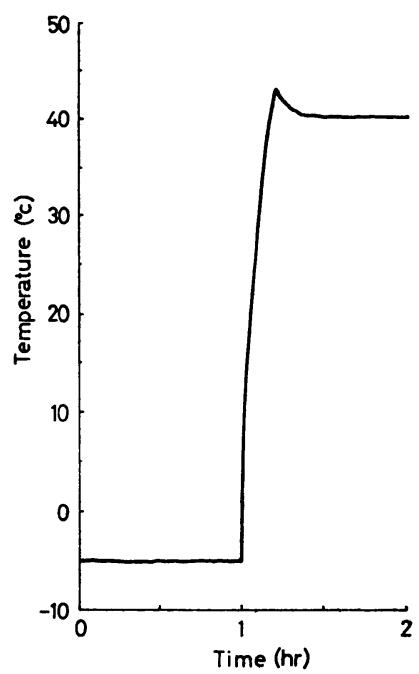

Fig. 13 Temperature-rise characteristic from $-5^{\circ} \mathrm{C}$ to $40^{\circ} \mathrm{C}$.

controller. Temperature control was programed from $10^{\circ} \mathrm{C}$ to $40^{\circ} \mathrm{C}$ with rising and falling gradient of temperature of $10^{\circ} \mathrm{C} / 30 \mathrm{~min}$. Controlled temperature sufficiently followed to the programed value. The cyclic variation was scarcely observed in the controlled temperature, and the control error was less than $\pm 0.5^{\circ} \mathrm{C}$. Humidity control was not affected by temperature variation and kept at $60 \% \pm 3 \%$. Figure 15 shows result of program control of relative humidity. Temperature 


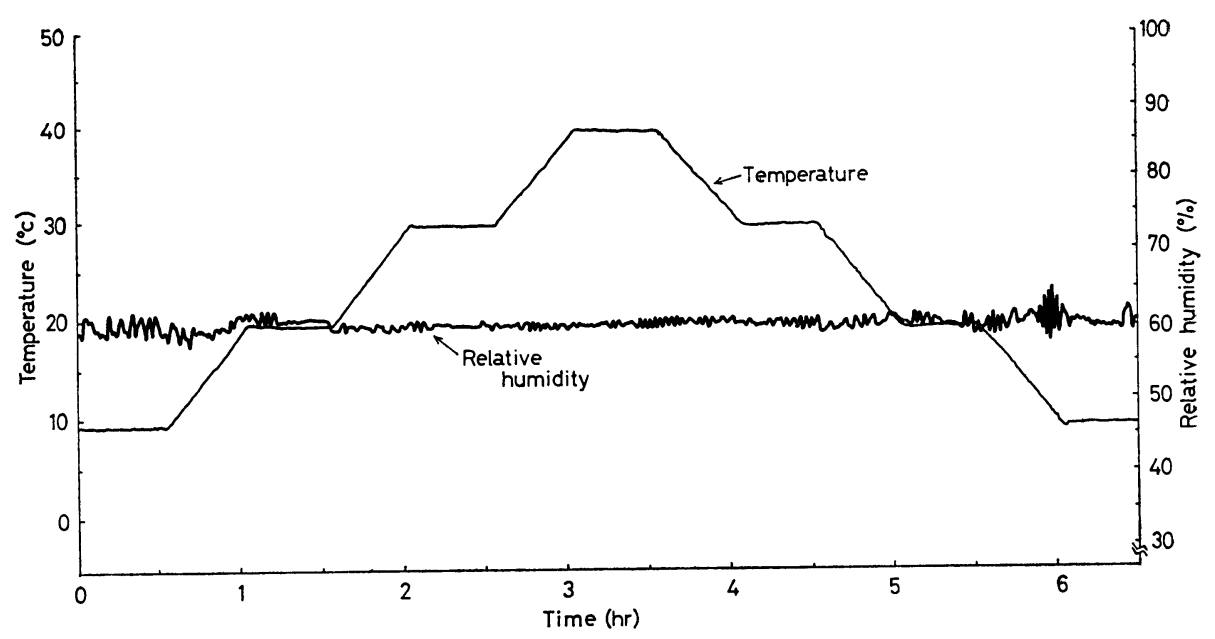

Fig. 14 Temperature controlled by the program controller.

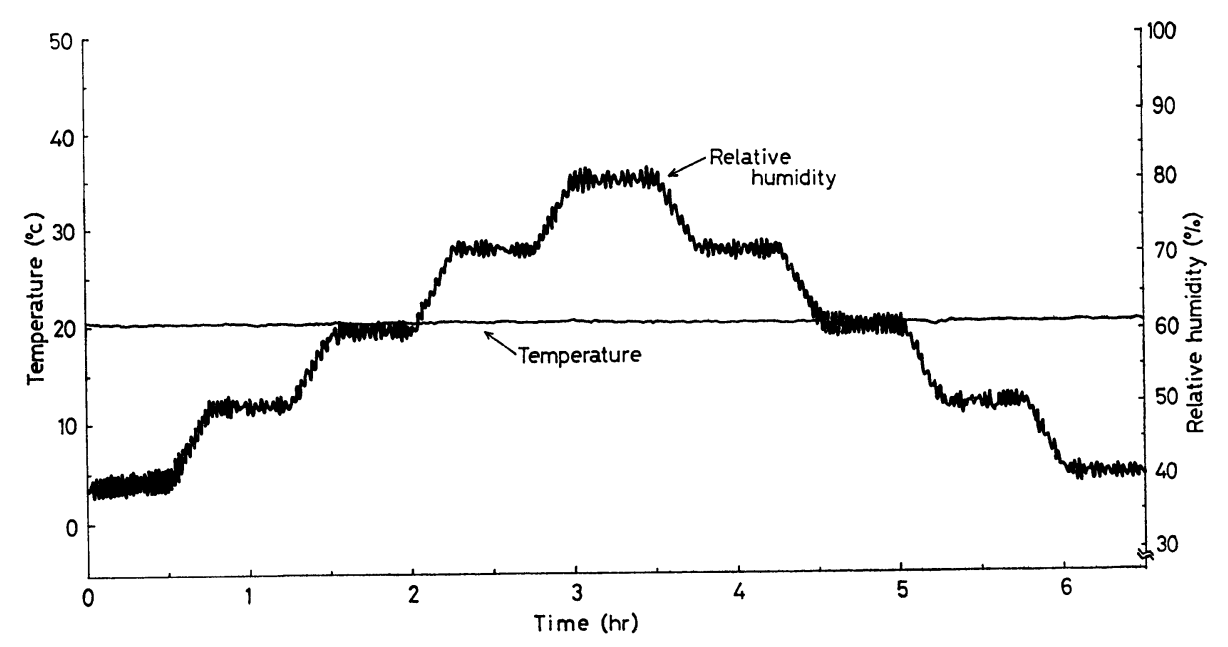

Fig. 15 Relative humidity controlled by the program controller at $20^{\circ} \mathrm{C}$.

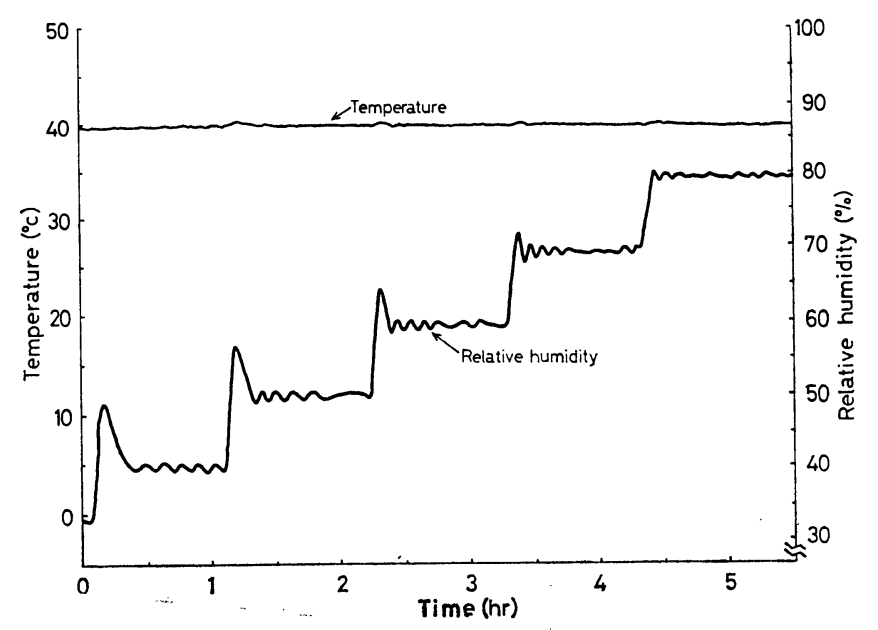

Fig. 16 Controlled relative humidity of $40,50,60,70$ and $80 \%$ at $40^{\circ} \mathrm{C}$. 
was set at $20^{\circ} \mathrm{C}$ and relative humidity control was programed from $40 \%$ to $80 \%$ with rising and falling gradient of 10\%/15 min. Desirable response of controlled relative humidity was obtained. Figurs 16, 17, 18 and 19 show the relative humidity controlled at ranges of $40,50,60,70$ and $80 \%$, when temperature was set at $40,30,20$ and $10^{\circ} \mathrm{C}$, respectively. At temperature of $10^{\circ} \mathrm{C}$, the accuracy of relative humidity control was relatively low. At temperature of 20,30 and $40^{\circ} \mathrm{C}$, relative humidity was controlled with sufficient accuracy. The off-set was effectively erased by the P.I.D. control action. Figure 20 shows temperature controlled by the sine wave generator. When the amplitude of the

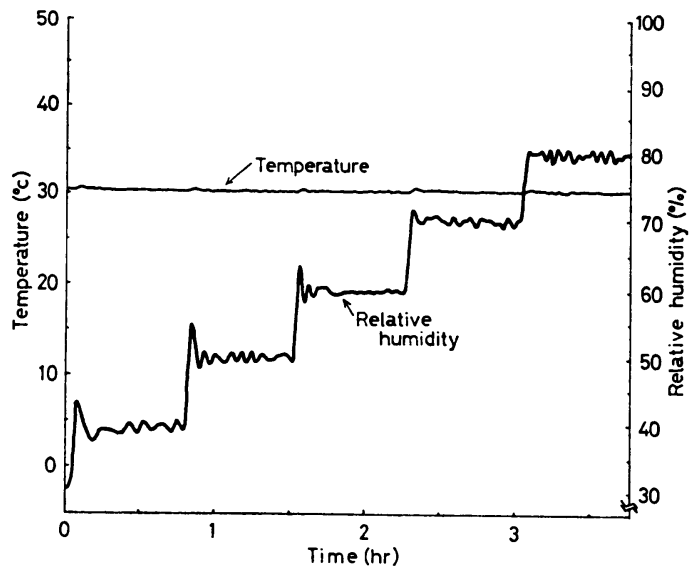

Fig. 17 Controlled relative humidity of 40,50 , 60,70 and $80 \%$ at $30^{\circ} \mathrm{C}$.

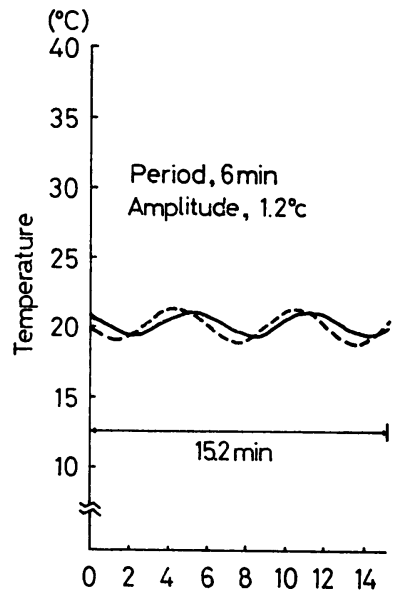

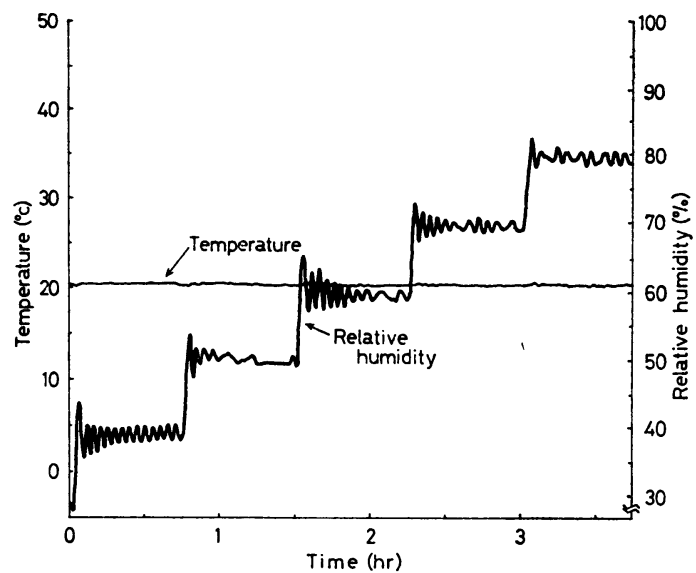

Fig. 18 Controlled relative humidity of 40,50 , 60,70 and $80 \%$ at $20^{\circ} \mathrm{C}$.

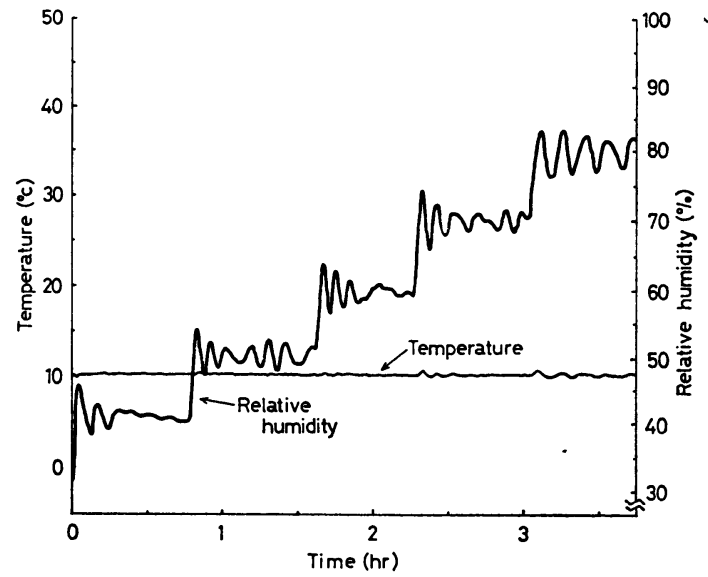

Fig. 19 Controlled relative humidity of 40,50 , 60,70 and $80 \%$ at $10^{\circ} \mathrm{C}$.

Fig. 20 Temperature controlled by sine wave generator at $20^{\circ} \mathrm{C}$.

- - - Pre-set sine wave signal _ Response signal 
wave was small, controlled temperature followed well to desired value. However, when the amplitude was large, controlled temperature was slightly different from the desired value. Figure 21 shows vertical distribution of light intensity at the centeral position of the growth compartment. At $50 \mathrm{~cm}$ above floor, 20,000 lux $\left(110 \mu \mathrm{W} / \mathrm{mm}^{2}\right)$ of light intensity was obtained. Figure 22 shows spectral intensity distribution of the light at $30 \mathrm{~cm}$ above floor. It is not clear whether this spectrum is suitable for plant, or not. For the measurement of distribution of wind velocity, space of the growth compartment was divided into 3 sections, and 27 points in total (9 points on each section) were selected. Figure 23 shows mean velocity at each of the measuring points and Fig. 24 shows fluctuation and distribution of wind velocity. On the section $A$, wind velocity is larger than that on other sections. Turbulent flow was observed on each measuring point, and the mean velocity ranged from $0.2 \mathrm{~m} / \mathrm{sec}$ to $0.5 \mathrm{~m} / \mathrm{sec}$.

From the results of performance, it could be estimated that the P.I.D. control action makes it possible to control temperature and relative humidity with high accuracy. The problem of illumination technique is remained. What kinds of artificial light is

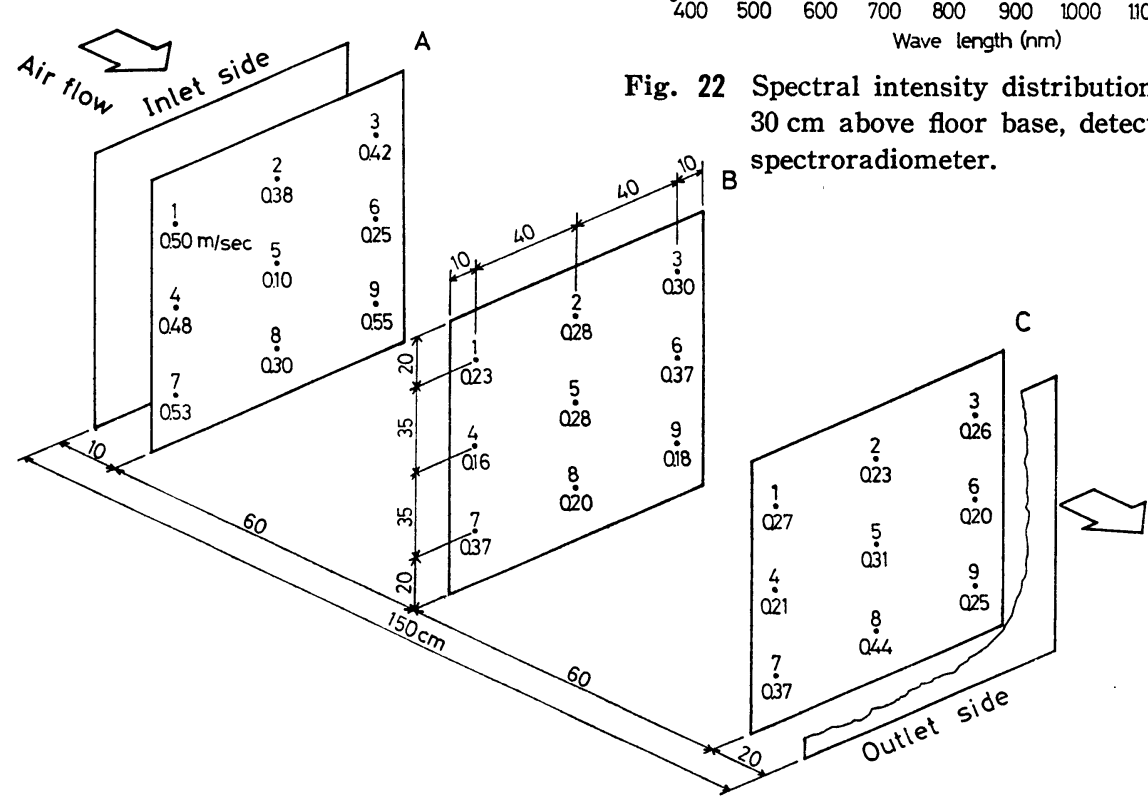

Fig. 23 Measuring points for wind velocity and mean velocity.

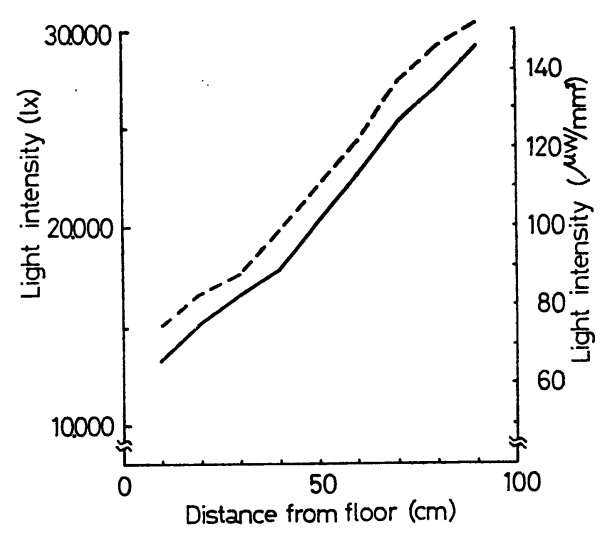

Fig. 21 Vertical distribution of light at central position. intensity (lux) detected by luxmeter. spectroradiometer.

--- , light intensity $\left(\mu \mathrm{W} / \mathrm{mm}^{2}\right)$ detected by gold-gold black vaccum thermocouple (JASCO radiometer, RMD-1). - light

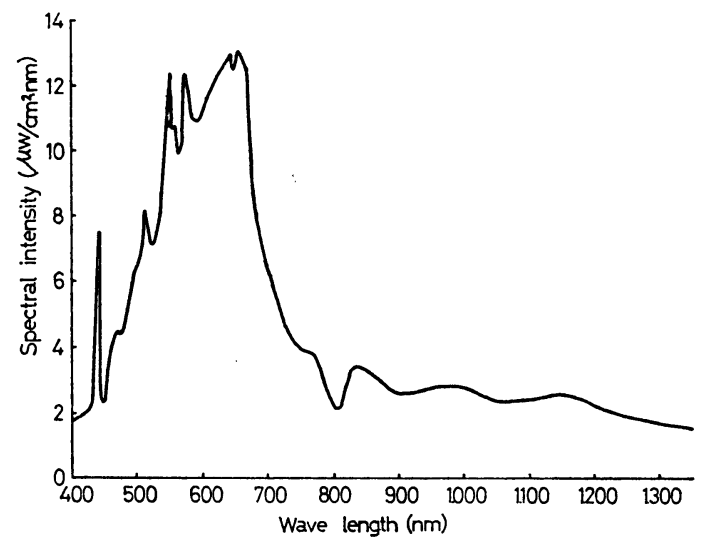

Fig. 22 Spectral intensity distribution of light at $30 \mathrm{~cm}$ above floor base, detected by ISCO 


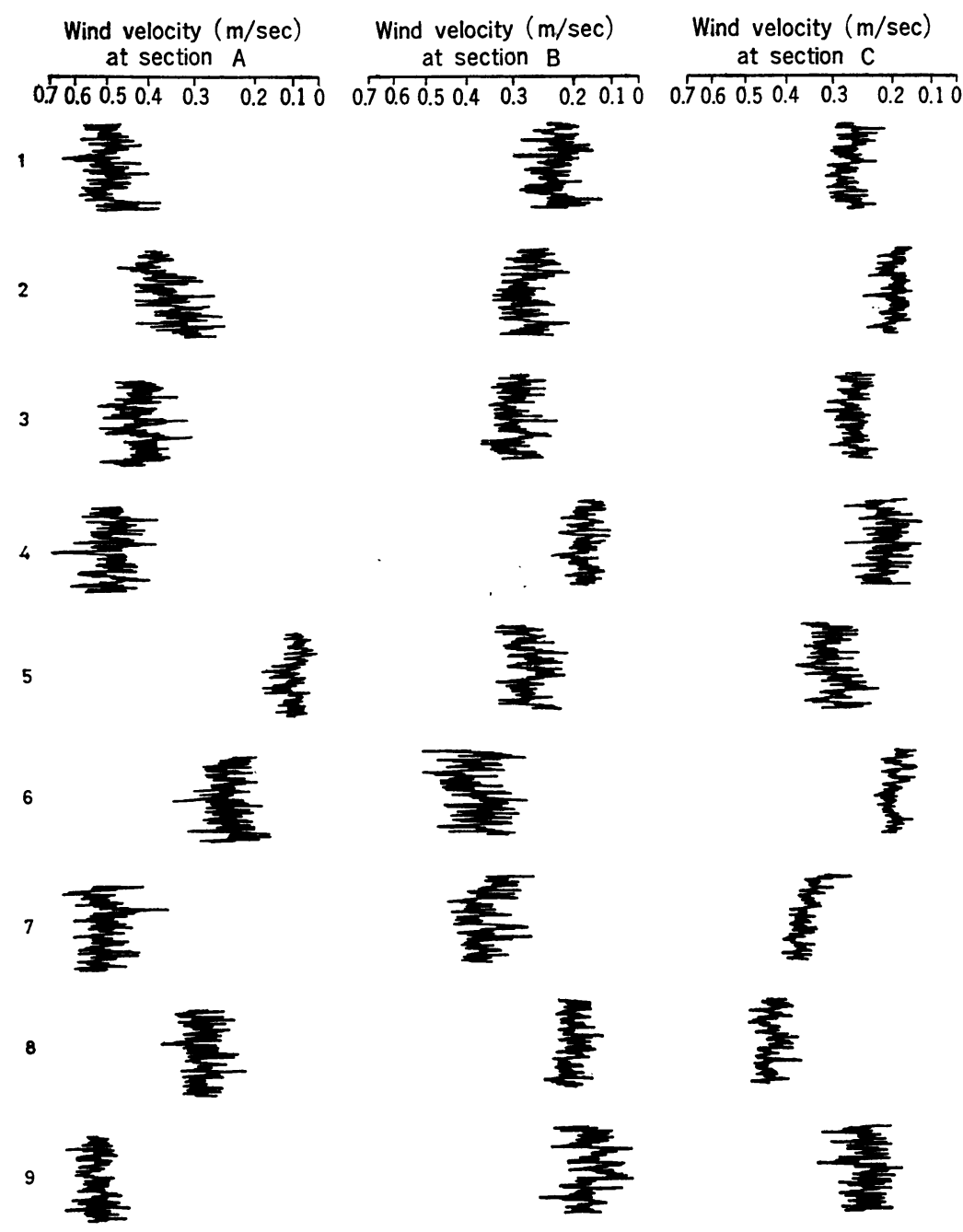

Fig. 24 Fluctuation and distribution of wind velocity in growth compartment detected by hot wire anemometer.

most suitable for plant, is not known. Perhaps, the light should be selected for the research purposes.

The authors acknowledge to Associate Professor Y. Hashimoto (Ehime University) for reading manuscript.

\section{REFERENCES}

(1) AshraE, 1967 System and equipment. In Guid and Data Book, p. 73-74.

(2) Evans, L. T. (ed.) 1963 Environmental Control of Plant Growth. Academic Press.

(3) MaEzAwA, K. 1962 Blind controller (Type EGC). Yokogawa Technical Report 6 (1) : 1316.

(4) WENT F. W. 1943 Plant growth under controlled conditions. I. The air-conditioned greenhouse at the California Institute of Technology. Amer. Jour. Bot. 30 : 157-163. 